\title{
Investigation of structure-function interaction of polyhedron of Bombyx mori Nuclear Polyhedrosis Virus (NPV) with polyhedra protease and RNA. 3. Polyhedras contain small RNA
}

\author{
E. A. Kozlov, M. I. Vudmaska ${ }^{1}$, M. T. Bobrovskaja, T. V. Shirina
}

The Institute of Molecular Biology and Genetics 150 Zabolotny Str., Kyiv 03143, Ukraine

The immunobiotechnological scientific industrial enterprise, Joint-stock company «Diaproph-Med» 35, Svetlitsky str., Kyiv, 04123, Ukraine

kozlov@imbig.org.ua

It was shown that polyhedras of Bombyx mori Nuclear Polyhedrosis Virus contain RNA with molecular weight of 17-18 kDa (50-60 nucleotides). This RNA is likely to belong to the minor RNA class and its origin is discussed.

Key words: nuclear polyhedrosis virus, polyhedra RNA, microRNA

Introduction. The results of our research on nuclear polyhedrosis virus (NPV) RNA of Bombyx mori have been first published in 1969 [1]. At that time we supposed that polyhedras contained large fragments of, most probably, polyhedrin mRNA. Supposedly polyhedras accidentally captured them during crystallisation. Therefore, further investigation on the nature of polyhedra RNA, to our opinion, had no sense whatsoever. However, the discovery of large DNA-containing viruses of minor RNA (microRNA, $\mathrm{miR}$, in particular), which play the role in numerous (C) E. A. KOZLOV, M. I. VUDMASKA, M. T. BOBROVSKAJA, T. V. SHIRINA,
2007 process as well as in the interactions between the virus and the cell [2-5] dated back to the 1990's/2000's encouraged us to renew previous investigation. The second article in this series [6] was dedicated to the clarification of the effect of protease and RNA of polyhedras on the association-dissociation of polyhedrin in the $\mathrm{pH}$ 10.5-11.00solutions. We have demonstrated that polyhedras contained RNP-complex with molecular weight of $20000-25000 \mathrm{Da}$, containing polypeptide, m.w. $10000-12000 \mathrm{Da}$. It is clear that molecular weight of such complex is around 10000 . However, as the polyhedrin solutions also included high-molecularRNP-complexes (13S and higher) [6], then minor RNP-complex may include the fragment of 
large RNA of unknown origin: at the condition of dissolving of polyhedras, high-molecular RNA, if it is initially present in polyhedras, may be destroyed, besides the presence of nuclease in polyhedras is also possible. Taking into account the facts listed above we have decide to investigate the nature of RNA, isolated by the method of dissolution polyhedras in $67 \%$ acetic acid or low alkaline solutions, which avoid the effect of enzymes [7]. The results of the investigation are given below.

Materials and Methods. Polyhedras. The polyhedras used were of proteolytic activity or were significantly lower activity-wise (polyhedras A and B) than those of newly isolated [6], or of no activity at all (polyhedras B). Polyhedras A were isolated of caterpillars of the $4^{\text {th }}-5^{\text {th }}$ age, died of NPV at natural conditions (decay); polyhedras B were of hemolymph of NPV infected caterpillars, stored for 20 years. Polyhedras B were isolated from homogenate of rotten cocoons.

Solvents. A - pH $10.5\left(0.05 \mathrm{M} \mathrm{Na}_{2} \mathrm{CO}_{3}+0.05 \mathrm{M}\right.$ $\left.\mathrm{NaHCO}_{3}+0.1 \mathrm{M} \mathrm{NaCl}\right) ; \mathrm{B}-67 \%$ acetic acid; $\mathrm{C}-\mathrm{pH} 7$ $(0.5 \%$ sodium sarcosyl $+25 \mathrm{mM}$ sodium citrate $+4 \mathrm{M}$ guanidine thiocyanate $+0.1 \mathrm{M}$ ?-mercaptoethanol).

Electrophoresis in 2\% agarose in Na-borate buffer was performed according to the method, described in [8], in gels, containing $2.2 \mathrm{M}$ formaldehyde (denaturated conditions) and without formaldehyde (native conditions). The samples were both added and not added formaldehyde. One and the same gel was exposed with ethidium bromide and then with coomassie brilliant blue. In the first case - the gels were exposed with either addition of the dye to the sample (method 1) or by the immersion of gel into ethidium bromide solution for 15 min with subsequent washing with distilled water for 20-30 min (method 2). It is noteworthy that extended washing eliminates the dye and minor RNA are not exposed. After capturing the photo, exposed with ethidium bromide, the gel was dyed with coomassie brilliant blue.

Electrophoresis in 15\% polyacrylamide gel (PAAG), containing DS-Na and 7M urea, was performed in accordance to specifically developed method for identification of minor RNA [9]. The samples were also added with $7 \mathrm{M}$ urea. One and the same gel was exposed with subsequent dyeing of RNA and the protein, as earlier described.
Isolation of RNA. Preparation $1-100 \mathrm{mg}$ of polyhedras were dissolved in $4 \mathrm{ml}$ of solvent $\mathrm{A}$ for 1 hour at the room temperature. The solution was centrifuged at $6000 \mathrm{rpm}(10 \mathrm{~min})$, and then at $3000 \mathrm{rpm}(60$ $\left.\min , 4^{\circ} \mathrm{C}\right)$. Supernatant $\mathrm{pH}$ index was decreased by dialysis against the phosphate buffer with $\mathrm{pH} 7.4$ and then RNA were extracted by water-saturated phenol in 2 times. RNAs were precipitated from the water by double volume of cooled alcohol. The sediment was doslved in phosphate buffer, $\mathrm{pH}$ 7.4, extracted two more times and RNAs were precipitate with alcohol.

Preparation 2-100 $\mathrm{mg}$ of polyhedras were dissolved in solution B for 1 hour at room temperature and centrifuged as earlier described. After centrifugation, supernatant was dialyzed during the night against the distilled water and then 15-20 min against $0.2 \mathrm{M}$ ammonium bicarbonate till the settling-out of polyhedrin in the dialysis bag. Suspense was moved to the centrifuged vial and the protein was precipitated by centrifugation at $6000 \mathrm{rpm}$. Supernatant was added with DS-Na to final concentration of $1.5 \%$ and RNA was extracted in accordance to earlier described method.

Preparation 3 - was prepared similarly to Preparation 2, except for polyhedrin was not precipitated, and RNAs were extracted after dialysis only against the distilled water, having added DS-Na.

Preparation 4-100 $\mathrm{mg}$ of polyhedras were dissolved in solution $\mathrm{B}$, the solution was centrifuged at $6000 \mathrm{rpm}$ for $10 \mathrm{~min}$ and RNAs were extracted from supernatant in accordance to earlier described method, but the mixture of phenol with chloroform (1:1) has been used.

Result and Discussion. As it has been shown [1], RNA, isolated from polyhedras A by the alkaline method ( $\mathrm{pH} 10.5$ ), was specific for UV spectrum with $E_{260} / E_{280}=1.85$ and hyperchromic effect of $20-22 \%$. Taking in this into account, we have supposed that the solutions contain high-molecular RNA and/or its large fragments. Current work is dedicated to verification of primarily these sort of RNA preparations. Fig. 1 shows that Preparation 1 RNA during electrophoresis at the native conditions shows significant diffusive band in the range of $\sim 10 \mathrm{~S}-\mathrm{S}$, which is lower than in the case of tRNA, while the range is broadened at the increase in the number of extractions from 2 to 4 . Yet in the case of 
two extractions, intensive RNA band in $5 \mathrm{~S}$ region is clearly seen. However, it contains insignificant admixture of protein, compared to the preparation after the $4^{\text {th }}$ extraction. Electrophoresis of Preparation 1, RNA at the denaturated conditions, revealed the range of RNA band to be significantly narrower from $5 \mathrm{~S}$ to $<5 \mathrm{~S}$ (Fig.2). At the same time, the maximum number of of RNA is specific for the higher mobility than tRNA. The decrease in polydispersibility of RNA at the electrophoresis of Preparation 1 at the denaturated conditions is clearly to be seen. As Preparation 1 was obtained by the dissolving of polyhedras in highly alkaline solution, therefore, to lower the possibility of RNA decoupling at these conditions, we isolated Preparation 2 of RNA, having dissolved polyhedras B in $67 \%$ acetic acid.

Fig.3 shows that 1 hour electrophoresis at the denaturated conditions is presented by more clear-cut RNA band, which is also specific for higher mobility, than tRNA. However, in 2 hours this band narrowed significantly, while the major part of dyeing was revealed in the range of $18 \mathrm{~S}-10 \mathrm{~S}$. To clear out the essence of this phenomenon and of the fact that polydispersity increases with the increase in the number of RNA extractions with phenol (Fig.2), we carried out the electrophoresis of RNA samples with the addition of formaldehyde. The results (Fig.4) show that the introduction of formaldehyde results in the major part of the dye moving towards the cathode, i.e. direction, opposite to RNA. It is obvious that seemingly higher polydispersibility of polyhedra RNA can be most likely explained by the washing off of the dye during the electrophoresis from RNA complex, due to the less firm binding to minor RNA of the latter, in the comparison with ribosomal RNA.

Summarising the aforementioned it is possible to conclude that the solution of polyhedras contains RNA with lower molecular weight after precipitation, than in the case of tRNA, and does not contain high-molecular RNA. However, in the case of Preparation 2 RNA it is possible that a part of RNA may be associated with polyhedrin during he precipitation of the latter. Meanwhile, as it has already been mentioned, in the case of Preparation 1 RNA, the effect of nucleases, the presence of which in the polyhedras have not been investigated, is also possible. Therefore, we have isolated
RNA preparations without precipitation of polyhedrin out of the polyhedras B solutions, isolated at the conditions, which eliminate the effect of mucleases and proteases. Fig. 5 shows that Preparation 2 of polyhedras B also contains RNA with higher mobility than the one of tRNA (band 1) and doe not contain high-molecular RNA. Preparations 3 and 4do not contain high-molecualr RNA, however they contain RNA with a little bit lower mobility, than the one of tRNA (bands 2 and 3, respectively). However, these preparations contained significant admixture of protein (Fig.5, $b$, bands 2 and 3), which looked similar to preparation 1 after two-time extraction with phenol (Fig.1, $b$, band 1). Obviously, the extraction of RNA from the solutions without precipitation of polyhedrin, RNA preparation can not be purified from the protein completely (these polyhedrin solutions contained $\sim 1 \%$ of RNA). Apparently, preparations 3 and 4 are the associate of protein with RNA of lower molecular weight, than that of tRNA, which is not disintegrated at the conditions of current electrophoresis. This supposition is confirmed by results of electrophoresis of the preparations 3 and 4 in PAAG, containing $7 \mathrm{M}$ urea. Fig.6, $a$ shows that both preparations, isolated from solution of polyhedras with no polyhedrin, contain RNA of higher mobility, than that of tRNA. Comparison of Fig. 5 and Fig. 6 makes it clear that dyeing of bands 2 and 3 with ehtidium bromide matches the dyeing of coomassie brilliant blue. However, the mobility of these bands, compared to the mobility of tRNA, is different - mobility in Fig. 5 is lower than in tRNA, and in Fig. 6 it is higher.

We suppose that electrophoresis of RNA of polyhedras in agarose (Fig.5) is protein-associated, while in the case of electrophoresis in PAAG both RNA and the protein are dissociated. It is obvious that dissociation takes place under the effect of $7 \mathrm{M}$ urea in both sample and gel. The fact that coomassie brilliant blue dyeing matches the dyeing of ethidium bromide show that, to our mind, the mobility of polypeptide of 14000 $\mathrm{Da}$ is similar to the one of polyhedras. As the mobility of tRNA (26000 Da) is the same as the peptide one (19 000-20 $000 \mathrm{Da}$ ), it is possible to suppose that molecular weight of RNA of polyhedras equals 17 000-18 $000 \mathrm{Da}$ (50-60 nucleotides). This RNA is most likely to belong to minor RNA. Polyhedras may 

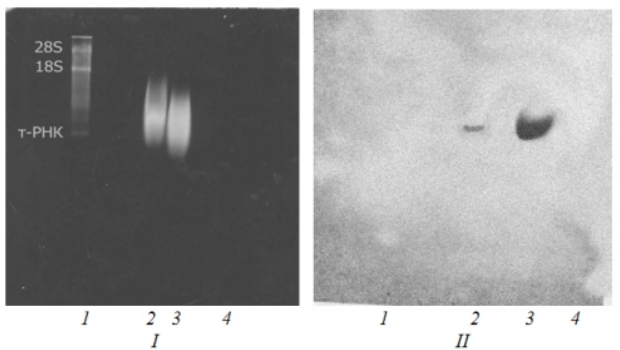

Fig.1 Electrophoresis in 2\% agarose at the native conditions of preparation $1 \mathrm{RNA}$, isolated from polyhedras A; time of electrophoresis $60 \mathrm{~min}, I$ - ethidium bromide (method 1) (dye added to the sample), $I I$ - coomassie brilliant blue $(1$ - ribosomal RNA marker, 2 - RNA of polyhedras, extracted two times; 3 - RNA of polyhedras, extracted 4 times, 4 - polyhedrin)
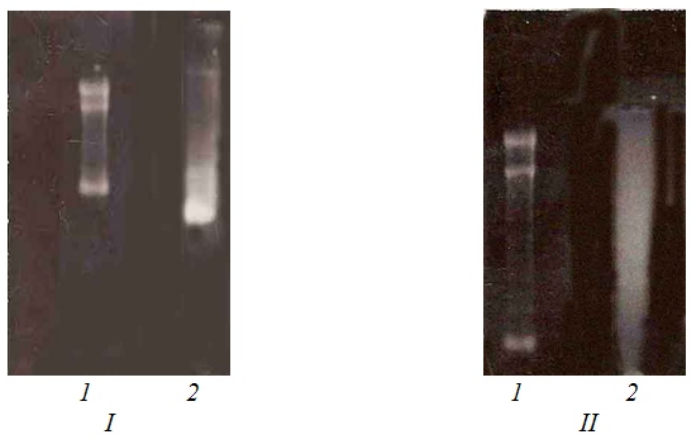

Fig. 3 Electrophoresis in 2\% agarose at the denaturated conditions of preparation 2 RNA, isolated from polyhedras B; time of electrophoresis $60 \mathrm{~min}, I$ - time of electrophoresis $60 \mathrm{~min}, I I$ - time of electrophoresis 120 min ( 1 - ribosomal RNA marker, 2 - RNA of polyhedras, extracted two times; 3 - RNA of polyhedras, extracted 4 times, 4 - polyhedrin); dye - ethidium bromide (method 1)
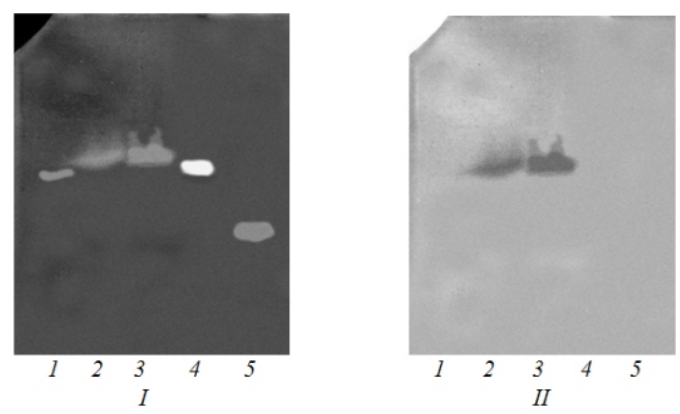

Fig. 5 Electrophoresis in $2 \%$ agarose at the denaturated conditions of preparation 2 RNA, isolated from polyhedras B; time of electrophoresis $60 \mathrm{~min},(I-$ ethidium bromide (method 2$)$ (immersion of gel into the dyeing solvent); $I I$ - coomassie brilliant blue) ( 1 preparation 2 of RNA of polyhedras; 2, 3-preparations 3 and 4 of RNA, respectively; 4 - tRNA of Escherichia coli; 5 - synthetic 25-member oligonucleotide

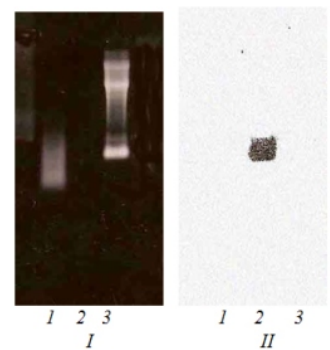

Fig. 2 Electrophoresis in 2\% agarose at the denaturated conditions of preparation $1 \mathrm{RNA}$, isolated from polyhedras A; time of electrophoresis $60 \mathrm{~min}, I$ - ethidium bromide (method 1) (dye added to the sample), II - coomassie brilliant blue (1 -RNA of polyhedras, extracted 4 times , 2 -polyhedrin ; 3 - ribosomal RNA marker)

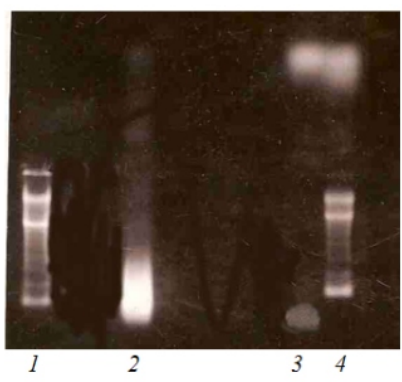

Fig.4 Electrophoresis in 2\% agarose at the native conditions of preparation $1 \mathrm{RNA}$, isolated from polyhedras A; time of electrophoresis $60 \mathrm{~min}$; dyeing with ethidium bromide (method 1) (1, 4ribosomal RNA markers, 2, 3 - RNA of polyhedras; 3, 4- the sample was added with formaldehyde)

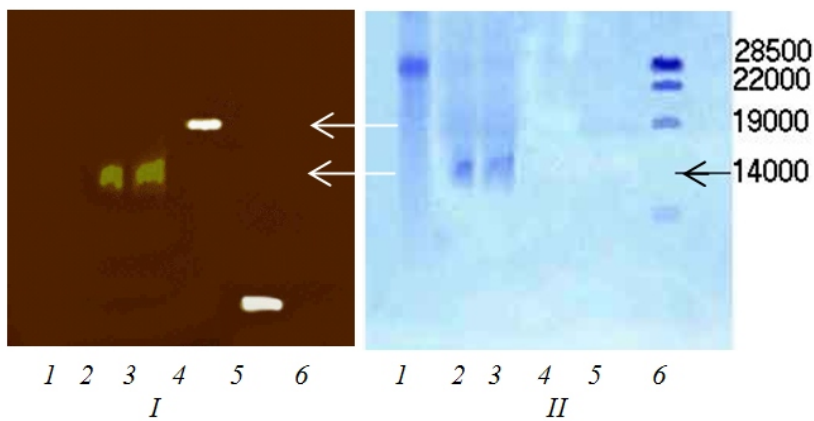

Fig.6 Electrophoresis in 15\% PAAG, containing DS-Na and $7 \mathrm{M}$ urea, of RNA preparations 3 and 4, isolated from polyhedras B; time of electrophoresis $90 \mathrm{~min}$; $I$ - ethidium bromide (method 2; II - coomassie brilliant blue) ( 1 - polyhedrin; 2, 3 preparations 3 and 4 of RNA, respectively; 4 - tRNA of E. coli; 5 - synthetic 25 -member oligonucleotide). Arrows indicate the position of polyhedrin fragments with corresponding molecular weights [10]. 
contain not only one but many minor RNA of the same molecular weight.

Where do minor RNA appear from? Recently, the term 'minor' RNA includes short, 19-28 nucleotide long, RNA of endogenic and exogenic origin, which participate in the protection mechanisms, controlling the processes of growth and differentiation of cells [11, 12], oncogenesis [13, 14], and development of eukaryotes [15-20], including the metamorphosis in insects [19]. The most numerous class of endogenic RNA is $\mathrm{miR}$. The first version of the appearance of $\mathrm{miR}$ in polyhedras is the host version. We have isolated polyhedras from larva of the $5^{\text {th }}$ age (polyhedras A and B), which often had already the cocoon formed (polyhedras B). This period in the life of insects is specific for some physiological changes due to the change from larva into a chrysalis. Evidently, this metamorphosis may be regulated by miR [19], synthesised throughout this period. In this case the capturing of host miR by polyhedras may be viewed as an attempt to detain the virus at a convenient stage of development of the host, i.e. at the "favourable" stage for the maximal accumulation of polyhedras. The second version of $\mathrm{miR}$ appearance in polyhedras is of viral origin. miR genes are detected in genomes of large DNA-containing viruses [5]. The functions of these $\mathrm{miR}$ in the replication of viruses or in the interactions of virus-cell are not clear. Possibly, DNA of NVP of baculoviruses may contain miR genes.

As the crystallisation of polyhedras is know to take place in the nucleus, than they may capture either the primary miR transcript (pri-miR) or miR precursor (pre-miR), which is processed out of pri-miR in the nucleus $[21,22]$. Usually pri-miR may contain from one to several hundreds (even 1000 and more) nucleotides. pri-miR are known to act as mRNA [23]. Polyhedras include RNA of 50-60 nucleotides, which is compatible to the size of pre-miR (usually 50-80 nucleotides). Probably, polyhedras are capable of selective capturing of products of pri-miR processing. mRNA may be the candidate for polyhedrin mRNA - the maximum translational product at this stage of infection [24]. From this standpoint it would be interesting to apply computer technologies of miR detection in polyhedrin gene [25]. Following publication in this series will be dedicated to the mentioned problem.

\section{Э. А. Козлов, М. И. Вудмаска, М. Т. Бобровская, Т. В. Ширина}

Исследование структурно-функциональных взаимодействий полиэдрина вируса ядерного полиэдроза тутового шелкопряда (Bombyx mori) с протеазой и РНК полиэдров. 3. Полиэдры включают малую РНК

Резюме

Показано, что полиэдры вируса ядерного полиэдроза В. mori содержат РНК с молекулярной массой 17- 18 кДа (50-60 нуклеотидов). Эта РНК, вероятно, принадлежит к классу малых РНК. Обсуждается ее происхождение

Ключевые слова: вирус ядерного полиэдроза, РНК полиэдров, микро-РНК.

\section{REFERENCES}

1. Козлов Э. А., Согуляева В. М., Левитина Т. Л., Верещак В., Серебряный С. Б. Очистка полиэдренного белка вируса ядерного полиэдроза тутового шелкопряда и исследование процессов его ассоциации-диссоциации в растворах // Биохимия.-1969.-39, № 4.-С. 679-684.

2. Ruvkun G. Glimpses of a tiny RNA world // Science.- 2001.294.-P. 797-799.

3. Zamore P. D. Ancient pathways programmed by small RNAs // Science.-2002.-296.- P. 1265-1269.

4. Krutzfeldt J., Poy M.N., Stoffel M. Strategies to determine the biological function of microRNAs // Nat. Gen.2006.-38.-S14.

5.Cullen B. R. Viruses and microRNAs // Nat. Gen.-2006.38. $-\mathrm{S} 25$.

6. Козлов Э. А., Ниязова Н., Бобровская М. Т., Ширина Т. В. Исследование структурно-функциональных взаимодействий полиэдрина вируса ядерного полиэдроза (ВЯП) тутового шелкопряда (Bombyx mori) с протеазой и РНК-полиэдров. 2. Влияние протеазы на диссоциацию полиэдрина в процессе гель-фильтрации через Sepharose 6В // Биополимеры и клетка.-2006.-22, № 3.-С. 192-200.

7. Hamilton A., Voinnet O., Chappel Z., Baulcombe. Two classes of short interfering RNA in RNA silencing // EMBO J.-2002.-21.-P. 4671-4679.

8. Maniatis T., Fritsch E., Sambrook J. Molecular cloning. A laboratory manual.-New York: Cold Spring Harbor Lab. press, 1982.-545 p.

9. Mette M. F., Autsatz W., van der Winden J., Matzke M. A., Matzke A. J. M. Transcriptional silencing and promoter methylation triggered by double-stranded // EMBO J.-2000.-19.-P. 5194-5201.

10. Kozlov E. A., Levitina T. L., Gusak N. M. The primary structure of baculovirus inclusion body proteins. Evolution and structure-function aspects // Curr. Top. Microbiol. and Immunol.-1986.-131.-P. 135-164.

11. Raftopoulou M. MicroRNA signals cell fate // Nat. Cell Biol.-2006.-8.-P. 112.

12. Boehm M., Slack F. J. MicroRNA control of lifespen and metabolism // Cell Cycle.-2006.-5.-P. 237-240.

13. Cousin J. Cancer biology. A new cancer player takes the study // Science.-2005.-310.-P. 766-767.

14. Ruvkun G. Clarification on miRNA and cancer // Science.-2006.- 311.-P. 36-37. 
15. Jover-Gil S., Candela H., Ponse M.R. Plant microRNAs and development// Int. J. Develop. Biol.-2005.-49.-P. 733-744.

16. Plasterk R. H. MicroRNA in animal development // Cell.-2006.-124.-P. 877-881.

17. Seggerson K., Tang L., Moss E. G. Two genetic circuits repress the Cenorhabditis elegans heterochronic gene lin-28 after translation initiation // Develop. Biol.-2002.-243.P. 215-225.

18. Sempere L. F., Sokol N. S., Dubrovsry E. B., Berger E. M., Ambros $V$. Temporal regulation of microRNA expression in Drosophila melanogaster mediated by normal signals and Broad-Complex gene activity // Develop. Biol.-2003.-259.P. 9-1.

19. Bashirullah A., Pasquinelli A. E., Kiger A. A., Perrimon N., Ruvkun G., Tummel C. S. Coordinate regulation of small temporal RNAs at the onset of Drosophila melanogaster metamorphosis // Develop. Biol.- 2003.-259.-P. 1-8.

20. Carrington J. S., Ambros $V$. Role of microRNAs in plants and animal develomment // Science.-2003.-310.P. 336-338
21. Lee J., Jeon K., Lee J.-T., Kim S., Kim V. N. MicroRNA maturation: stepwise processing and subcellular localization // EMBO J.-2002.-21.-P. 4663-4670.

22. Zeng J., Ji R., Cullen B. R. Recognition and cleavage of primary microRNA precursors by the nuclear processing enzyme Drosha // EMBO J.-2005.-24.-P. 138-148.

23. Cai X., Hagedorn C. H., Cullen B. R. Human microRNA are processed from capped, polyadenylated transcripts that can also function as mRNA // RNA.-2004.-10.-P. 1957-1966.

24. Okano K., Vanarsdall A. L., Mikhailov V. S., Rohrman G. F. Conserved molecular systems of Baculoviridae // Virology.-2006.-344.-P. 77-87.

25. Berezikov E., Cuppen E., Plasterek H. A. Approaches to microRNA discovery // Nature Gen.-2006.-38.-S2.

УДК 576.858 .77

Надійшла до редакції 27.10.07 